H. C., Ann. N.Y. Acad. Sci., Monograph on Autoimmunity, 1965, in press.

K., Fed. Proc., 1964, 23, 341.

van der Geld, H., Strauss, A. J. L., Kemp P. G., jun., and Exum, E. D., ibid., 1964, 23, 342 .

Osserman, K. E., and Weiner, L. B., Ann. N.Y Acad. Sci., Monograph on Autoimmunity, 1965 in press.

Strauss, A. J. L., van der Geld, H., Smith, C. W., McFarlin, D. E., Barlow, M., Cage, G. W., Ann. N.Y. Acad. Sci., Cont

12 McFarlin, D. E., Engel, W. K., and Strauss, A. J. L., ibid., 1965, in press.

13 Grob, D., Himei, H., and Namba, T., f. clin. Invest., $1964,43,1273$.

\section{The Nature of Cancer}

SIR,-In mongolism the accidental chromosomal change seems undoubtedly the cause of the condition. In chronic leukaemia chromosomal changes may occur in the leukaemic cells. Are these changes the result of the leukaemic process or are they the cause of it ? The appearance of chromosomal and mitotic changes in the cells of "cancer-insitu " (16 January, p. 154) suggest that these changes (whatever produces them) cause the cells in which they occur to behave riotously, producing a situation for which the body as a whole has no mechanism for its co-ordination.

As all malignant cells behave essentially in the same way-are invasive, produce metastases, lead a successful parasitic life-the process at work is obviously the same in all. Such process must surely be based on a normal one. During the individual's development the only time when a change occurs in the chromosomal arrangement is when certain panpotential cells no longer throw off soma cells but undergo reducing divisions to form gametes. What are the factors that operate to cause this sudden change after many divisions of somatic type with the full complement of chromosomes? Is it age ? Is it propinquity to certain somatic arrangements ? Is is due to a hormone produced elsewhere ? Do several factors operate? No one would suggest it is a virus. Is not the malignant process basically the same but uncoordinated, inchoate, and useless? The altered chromosomes produce cultures of parasitic cells which have no place in the victim's ontogeny. If we could find out what produces the sudden normal change to form gametes instead of soma cells, we may find that the same factors cause an old soma cell to become malignant by altering its chromosomes. The fertilized ova produces panpotential cells capable of giving rise to soma cells and gametes. The soma cells sacrifice their capacity to form sex cells in order to produce a body to protect and nourish the line of sex cells. There is every reason to suppose that in the somatic cells this capacity to form sex cells is only inhibited, not abolished. When after many generations a line of cells is growing old, when it is existing under conditions of stress and is receiving oft-repeated chemical or mechanical insults, when even it may be handicapped by acquiring a virus, the time may come when the hitherto dominant somatic side of the cell wanes and the suppressed gametoid side attempts to express itself by changes in the chromosomes and their arrangement. The result is not the production of a normal sex organ but a culture of parasitic invasive cells.

One may sum up by saying that the cancerous process is an attempt, by groups of

cells about to perish after a long life and many insults, to prevent extinction by doing the best they can to prepare for the production of gametes. The result is a disorderly invasive tissue, not under control because not provided for in ontogeny.

Surely this view, the perversion of a normal process, is more likely to be correct than the theory that malignancy is due to a chance mutation in somatic cells. In any case why should the chance mutation always bring about the same result ?

One is apt to be enamoured of one's own views, but I trust, if my theory is unreasonable or untenable, someone with as much right to criticize it as I have to propound it will state the grounds of objection. I taught it for many years and may have been wrong. Under the title "Gametoid Theory of Cancer," I contributed a letter to the Lancet ${ }^{1}$ outlining my theory in more detail and giving earlier references to it. I hope this will be consulted. It was written before the importance of the chromosomal changes in the very beginning of the malignant change was recognized.-I am, etc.,

University of Adelaide, John B. Cleland. Adelaide, South Australia.

\title{
REFERENCE
}

1 Cleland, J. B., Lancet, 1959, 1, 836.

\section{Treatment of Cystinuria}

SIR,-We were interested to hear Dr. $M$ Lotz and Dr. F. C. Bartter's comments (27 March, p. 855) on our paper (13 February, p. 403). We look forward to hearing more details of their work on cystinuria from their papers still in press. We must admit that we have not used low methionine diets at all in the routine treatment of cystinuria. The reason for this is that in our earlier paper we studied low protein intake as a means of lowering methionine intake and found that it did not make much difference to the cystine output, unless it was so low as to produce negative nitrogen balance. We have not been convinced by the literature so far which has claimed more success than we have had with low methionine diets. Recently in the treatment of homocystinuria we have had some experience with more specific low methionine diets in which total nitrogen intake was comparatively normal. These diets are an infernal nuisance to prepare and take, and while well justified in a serious condition such as homocystinuria ${ }^{2}$ they are hardly applicable as lifelong treatment in cystinuria with it relatively benign metabolic defect. Furthermore, there are theoretical arguments which suggest that depleting the dietary intake of methionine in a disease already causing grossly excessive loss of cystine could eventually produce an amino-acid deficiency. We look forward to hearing about the results of an actual therapeutic trial, especially if they are contrary to what we have been expecting. -We are, etc.

C. E. Dent.

M. FRIEDMAN

H. GrEen.

L. C. A. Watson.

University College Hospital Medical School

\section{REFERENCES}

1 Dent, C. E., and Senior, B., Brit. 7. Urol., 1955, 27, 317. arson, N. A. J., Dent, C. E., Field, C. M. B. B.
and Gaull, G. E., J. Pediat., 1965, 66, 565.

\section{Medical Orthopaedics}

SIR,- "Training in ophthalmology is largely surgical. Yet a large number of patients who consult ophthalmologists suffer from conditions which cannot be relieved by operation and are frequently ill-understood. ... . Consequently there has been a move by ophthalmologists in the last few years to establish medical ophthalmology clinics staffed jointly with physicians." I quote from the B.M.F. (10 April, p. 942).

Were the word " orthopaedics" substituted for "ophthalmology," the situation would be equally well described. Most musculoarticular disorders pose problems that are not amenable to surgery; yet the orthopaedic surgeon sees innumerable cases of, for example, backache, painful shoulder, or sprained knee, although the remedy is seldom an operation. Few would be sorry to refer such cases to a medical colleague, if one existed, with a primary interest in such diseases.

For this reason I have for many years recommended that the orthopaedic team should include an orthopaedic physician. In fact this concept has now been accepted at St. Thomas's Hospital, where earlier this year an orthopaedic physician was appointed.

This appears to me a move that should be as widely acknowledged as the ophthalmologists'; for it is unreasonable to expect promising young men to come for a grounding in orthopaedic medicine when they and I know that there are, as yet, no posts of this sort for them to go to on leaving their teaching hospital.-I am, etc.,

London W.1.

JAMES CyRIAX.

\section{Oral Contraception and Carcinoma}

SIR,_ "The pill" has been used as a contraceptive for many years now and yet, in spite of the many fears, there has been no corroborative evidence that it causes genital cancer. It is here suggested that its principal ingredient-namely, progesterone (progestogen)_-does not cause cancer, but indeed confers protection. We might therefore consider this as a "bonus" from "the pill."

It is well known that the prolonged action of oestrogen alone-for example, the patient over 40 years of age who is not ovulatingon the endometrium causes hyperplasia and cystic changes, and it is this rapid multiplication and proliferation of the cells which has been described as a possible precursor of endometrial carcinoma.

A woman taking " the pill" regularly is " injecting" into her circulation a synergistic combination of oestrogen and progesterone (=physiology). Therefore, instead of ever having a hyperplastic endometrium she will always tend to have a premenstrual-type endometrium with glandular and secretory changes. However, if a woman has already developed a thick endometrial hyperplasia it is possible to return this to the normal secretory phase by her taking a regular cyclical course of progesterone-e.g., " the pill." It is interesting to consider the well-known fact that the infertile woman (or the woman of low fertility) is more likely to develop endometrial carcinoma than the woman who has a large family. Possibly the former's reduced infertility was due to infrequent ovulation, 
and among this group of patients there is a higher instance of endometrial hyperplasia.

So much for cancer of the endometriumthat is, cancer of the corpus uteri. "The pill" is known to alter the cytology of a cervical smear, but there is still no evidence that it causes carcinoma of the cervix. Anyway, unlike the endometrium, the health of the cervix can so easily be watched by means of frequent cervical smears. The cause of carcinoma of the ovary remains a mystery, and even the most enlightened research worker would find it difficult to connect the cause with " the pill."

To summarize: From the cancer point of view it is my opinion that those women using "the pill" as a contraceptive may be thoroughly reassured. But in so doing, of course, it must be firmly remembered that intermenstrual spotting, a common side-effect in patients using " the pill " regularly, should be regarded with some suspicion.-I am, etc.,

$$
\begin{gathered}
\text { Department of Obstetrics } \\
\text { and Gynaecology, } \\
\text { St. John's Hospital, } \\
\text { Chelmsford, Essex. }
\end{gathered}
$$

David B. Brown.

\section{Treatment of Fits in Childhood}

SIR,-Your emphasis on establishing and maintaining a good airway is welcome (17 April, p. 1012).

Phenobarbitone is unsuitable for immediate control because when given in adequate dosage it is liable to cause respiratory depression, and barbiturates can cause vomiting, as Carnegie notes in a valuable review of this problem. ${ }^{1}$

For the newborn chloral and for older children paraldehyde is preferable, as described by Carnegie. ${ }^{1}$ The dose recommended by the Clevedon Study Group was $0.2 \mathrm{ml} . / \mathrm{kg}$. body weight. ${ }^{2} \quad$ McGreal $^{3}$ advised $0.3 \mathrm{ml} . / \mathrm{kg}$. Sterile paraldehyde in sealed glass ampoules and a glass syringe are used. They are desirable items in every general practitioner's bag.

In a hospital ward or casualty department, once the airway is established, blood should be taken for later blood-sugar estimation and glucose given intravenously. If there is no response in two minutes then paraldehyde is given.

Shanks" recommends giving phenytoin 50$100 \mathrm{mg}$. intramuscularly in addition to the paraldehyde. It has a slight stimulant action on the respiration.-I am, etc.,

London S.W.1.

Ronald Mac Keith. REFERENC̣ES

Carnegie, D. M., Develop. med. Child. Neurol., $1964,6,183$.

Bax, M. C. O., and Mitchell, R. G., Acute Hemiplegia in Childhood, 1962. Spastics Society and

3 McGreal, D. A., Practitioner, 1958, 181, 719.
4 Shanks, R. A., Cerebr. Palsy Bull., 1961, 3, 583.

SIR,-YYour editorial on this subject (17 April, p. 1012) once more enshrines "febrile convulsions" as a diagnostic category. May I suggest that fever is only one of a number of physiological upsets which may precipitate a fit-often more readily in children than in adults. It should be regarded simply as one occasion for fits of which the cause is either a pre-existing local brain lesion or "idiopathic" epilepsy (the term is used with a realization of its shortcomings). "Febrile convulsions" may be adequate phenomenology; as a diagnosis they should follow "teething convulsions" into the discard, and make way for a more rational approach to the diagnosis of fits in childhood.

This is not an argument for labelling as epileptic all those who have an occasional fit in childhood: only a plea for distinguishing clearly between description and diagnosis in medicine.- I am, etc., The Radcliffe Infirmary,
Oxford. W. M. Whitty.

SIR,-Your leading article on this subject (17 April, p. 1012) does not mention hypoglycaemia as an aetiological factor. It is, of course, an important, though perhaps uncommon, condition which requires prompt treatment to prevent cerebral damage. A baby with convulsions should be immediately admitted to hospital, where an estimation of blood glucose should be included among other urgent investigations (serum calcium and C.S.F.).-I am, etc.,

Royal Belfast Hospital for Sick Children.

$$
\text { R. N. SRIvastava. }
$$

\section{Potentially Dangerous Forms of Drug Economy}

SIR,-Dr. K. S. Zinnemann in his recent letter (17 April, p. 1067) drew attention to the possible dangers of using what he considers to be inadequate doses of ampicillin (Penbritin) or tetracycline for long-term prophylactic treatment of chronic bronchitis. $\mathrm{He}$ stated that the manufacturers of ampicillin are not acting in the best interests of bronchitic patients in suggesting, for prophylactic treatment, one capsule (250 mg.) of ampicillin every 12 hours.

This dosage has been recommended by an eminent authority ${ }^{1}$ and is therefore included in our literature. It is, of course, fully appreciated that the long-term, small-dose prophylactic use of antibiotics in the treatment of chronic bronchitis is controversial, and for this reason we state that "when continuous daily treatment is considered desirable, one capsule $(250 \mathrm{mg}$.) is recommended every 12 hours." We would certainly welcome more prolonged and intensive investigation into the most effective long-term continuous therapy, and our recommendations, which are under constant review, will be changed as appropriate.

For those who consider that long-term prophylactic use of small doses is not "desirable," two other higher dosage regimes are included in our literature, and these are also based on clinical usage.-I am, etc.,

E. T. KNUDSEN,
Medical Director,
Beecham Research Laboratories
Brentford, Middlesex.
Reference
1 Oswald, N., Practitioner, 1964, 193, 735.

\section{Abortion Law}

SIR,-Your leading article (17 April, p. 1009) gave admirable publicity to the possibility of significant reform of the law on abortion and it is to be hoped it will encourage the medical profession to clarify its position on this subject. Despite a recommendation for a change in the law by a B.M.A. committee on abortion in 1963, few gynaecologists would seem to support such a measure and significantly few doctors appear to be members of the Abortion Law Reform Association.

The decision regarding the deliberate destruction of any pregnancy is one that most doctors would wish to have made by the medical profession. Few would countenance direction from the state, the law, or by the patient herself. In consequence the law relating to abortion should be so framed as best to assist doctors who are called upon to undertake these difficult decisions.

The consultation is peculiar in that the patient does not come for advice but in the hope that she will be able to persuade the gynaecologist to undertake a certain course of action. He may well agree that the pregnancy is wholly undesirable but still be uncertain regarding the ultimate effect of such procedures upon her physical, spiritual, and emotional health, upon society, and also upon himself and his assistants. The advice of the family doctor may well be of more help to him than the opinion of a psychiatrist without prior knowledge of the patient.

Fortunately the present permissive state of the law seems ideal for the exercise of impartial medical judgment. It is sufficiently forbidding to give patients proper respect for the gravity of the action they demand, while lenient enough in operation to allow doctors to act in the best interest of each patient. It would be interesting to know how many gynaecologists would alter their present practice in the event of the abortion law being changed.-I am, etc.,

Birmingham 15: WILFRID G. MILls.

SIR,-If the medical argument on abortion were the last word it would already have been said and the matter would have lost all public interest. For, as your admirable leading article (17 April, p. 1009) made clear, the grounds for therapeutic abortion, if not unanimously agreed in detail, are amply covered by the law as it stands.

However, thanks to the skilled agitation of those who, for whatever motive, advocate amendment, the medical aspect has become almost secondary. For while on the one hand we have the learned arguments of Mr. Glanville Williams, there is, on the other, Mrs. Lena Jeger, M.P., who pleaded eloquently in the Guardian of 24 November 1964 for what she called " mankind's fifth freedom," the freedom to abort, as the only answer to the population explosion.

If a reform in the terms of the measure you attribute to Mr. Williams were to reach the Statute Book there is no reason to suppose that the response would be less than was the experience of Sweden. There, in the eleven years until 1961, following the introduction of a permissive law, the number of abortions, now legal, multiplied twelve times.

Gynaecologists would find themselves faced with a demand and pressure for abortions as a right, under the N.H.S. Would it not be wise for, say, the Royal College of Obstetricians and Gynaecologists to issue a definitive statement, from their immense authority in 